\title{
PEMANFAATAN WEB APPLICATION DALAM PENINGKATAN EFISIENSI DAN EFEKTIFITAS KERJA ADMINISTRASI (STUDI KASUS: PEMESANAN DAN PEMBUATAN SURAT KETERANGAN)
}

\author{
Reina \\ Jurusan Teknik Informatika, Fakultas Ilmu Komputer, Universitas Bina Nusantara \\ Jln. K.H. Syahdan No. 9, Palmerah, Jakarta Barat 11480 \\ reina@binus.edu
}

\begin{abstract}
The purpose of this study was to determine the extent to which the use of a web application to improve efficiency and effectiveness of administrative work. The research method used consisted of the analysis phase, study libraries to support application design and data collection based on observations. Results of evaluation and observation data before and after implementation of the system showed that the use of a web application to improve efficiency and effectiveness of administrative work, e.g. by decreasing the length of time the making of letter, an increase in the percentage of the making of timeliness, accuracy of data validation and provide facilities for students in order letter as well as convenience for staff in the making of letter. Another thing is the ease in monitoring the accuracy of the making of letter.
\end{abstract}

Keywords: web application, efficiency, effectiveness

\begin{abstract}
ABSTRAK
Tujuan penelitian ini adalah untuk mengetahui sejauh mana pemanfaatan web application dapat meningkatkan efisiensi dan efektifitas kerja administrasi. Metode penelitian yang digunakan terdiri dari tahap analisis, studi pustaka untuk menunjang perancangan aplikasi dan pengumpulan data berdasarkan observasi. Hasil evaluasi dan pengamatan data sebelum dan setelah implementasi sistem menunjukkan bahwa dengan pemanfaatan web application dapat meningkatkan efisiensi dan efektifitas kerja administrasi, yaitu dengan penurunan lama waktu pembuatan surat, peningkatan persentase ketepatan waktu pembuatan surat, keakuratan validasi data dan memberikan kemudahan bagi mahasiswa dalam melakukan pemesanan surat serta kemudahan bagi staf dalam pembuatan surat. Hal lainnya adalah kemudahan dalam melakukan monitoring ketepatan pembuatan surat.
\end{abstract}

Kata kunci: web application, efisiensi, efektifitas 


\section{PENDAHULUAN}

\section{Latar Belakang}

Dunia maya berkembang dengan begitu pesatnya. Saat ini internet sudah bukan merupakan aspek tambahan yang mendukung perkembangan bisnis, melainkan telah menjadi hal pokok yang harus dimanfaatkan semaksimal mungkin. Semua pelaku bisnis berlomba-lomba untuk memanfaatkan internet guna meningkatkan efisiensi dan efektifitas proses bisnis yang dimilikinya. Melalui internet, maka keterbatasan jarak dan waktu sudah bukan lagi menjadi penghalang untuk melakukan komunikasi, bertukar informasi, dan melakukan bisnis. Sejalan dengan berkembangnya hardware, perkembangan software pun tidak kalah cepatnya. Perkembangan software yang mendukung peningkatan penggunaan internet pun terus meningkat. Oleh karena itu, pengembangan web application untuk membantu proses bisnis guna meningkatkan efisiensi dan efektifitas proses terus meningkat sejalan dengan meningkatnya kebutuhan.

Hal ini pula yang mendorong Student Service Center (SSC) pada Universitas Bina Nusantara untuk memanfaatkan web application guna menjawab kebutuhan meningkatnya proses administratif yang harus dilakukan. SSC merupakan sebuah unit layanan administrasi dimana salah satu layanan yang diberikan adalah penyediaan surat keterangan yang dibutuhkan oleh mahasiswa. Beragamnya jenis surat dan meningkatnya jumlah mahasiswa yang berdampak pada meningkatnya kebutuhan penyediaan surat keterangan, mencetuskan ide untuk memanfaatkan web application sebagai interface guna membantu proses pemesanan dan penyediaan surat keterangan.

\section{Tinjauan Pustaka}

Web service adalah sarana yang menyediakan sebuah interface ke dalam aplikasi yang dikembangkan dengan menggunakan platform berbasis objek seperti .NET, COM, dan J2EE. Web service adalah interface aplikasi bukan interface objek (Wall dan Lader, 2002: 220). atau intranet.

Web application adalah sebuah aplikasi yang diakses melalui sebuah jaringan seperti internet

Definisi efisien yang pertama adalah menjadi efektif tanpa membuang uang, usaha, atau waktu. Kedua adalah tepat atau sesuai untuk mengerjakan (menghasilkan) sesuatu dengan tidak membuang-buang waktu, tenaga, atau biaya. Ketiga adalah bekerja secara produktif dengan pengeluaran usaha dan biaya yang kecil.

Definisi efektif yang pertama adalah mampu mencapai suatu maksud. Kedua adalah dapat membawa hasil. Ketiga adalah sanggup menghasilkan hasil yang diinginkan.

\section{METODE}

Metode yang digunakan dalam penelitian meliputi 3 tahapan. Tahap pertama adalah analisis kebutuhan sistem dengan mempelajari proses bisnis yang ada. Dilakukan analisis atas proses pemesanan dan pembuatan surat yang berjalan. Dimana pemesanan dan pembuatan surat masih dilakukan secara manual. Dalam tahap ini dilakukan survei atas proses yang dilakukan.

Tahap kedua adalah studi pustaka untuk perancangan dan pembuatan web application. Perancangan yang dibuat disesuaikan dengan kebutuhan, dimana mahasiswa dapat melakukan pilihan 
atas jenis surat, memberikan informasi yang dibutuhkan dalam pembuatan surat, sehingga bentuk tampilan menjadi interaktif dan user friendly.

Tahap ketiga adalah pengumpulan data pesanan surat serta pengamatan data sebelum dan setelah sistem diterapkan guna mengukur tingkat efisiensi dan efektifitas pemanfaatan sistem. Data yang didapat adalah data tahun 2007, 2008 dan 2009. Dimana data tahun 2007 adalah data sebelum implementasi sistem dan data tahun 2008 dan 2009 adalah data setelah implementasi sistem.

\section{HASIL DAN PEMBAHASAN}

\section{Gambaran Umum Sistem Berjalan}

Proses pemesanan surat yang berjalan sebelumnya dilakukan secara manual, dimana mahasiswa datang ke SSC untuk melakukan pemesanan dengan mengisi buku pesanan, memberikan informasi terkait dengan kebutuhan surat seperti tujuan pembuatan surat, nama dan alamat perusahaan. Kemudian staf akan memvalidasi informasi yang dituliskan oleh mahasiswa. Selain informasi yang divalidasi, staf juga akan memvalidasi apakah surat keterangan yang dipesan sesuai dengan status mahasiswa. Contoh untuk surat keterangan mahasiswa aktif, maka hanya mahasiswa yang terdaftar aktif, yaitu mahasiswa yang memiliki jadwal kuliah di semester tersebut, yang diijinkan memesan. Untuk mahasiswa yang melakukan pemesanan surat pengantar survei skripsi adalah mahasiswa yang sudah terdaftar mengambil mata kuliah skripsi. Jika informasi dan status mahasiswa valid, maka akan dilanjutkan dengan pembuatan surat dengan menggunakan MS Word. Informasi yang dibutuhkan dalam pembuatan surat, seperti nama perusahaan dan alamat perusahaan akan diketikan oleh staf. Surat yang telah selesai dicetak, dimintakan tanda tangan pejabat berwenang dan staf menuliskan tanggal selesai pembuatan surat pada buku pesanan. Hal ini menyebabkan sulitnya proses monitoring dalam ketepatan waktu pembuatan surat.

Berdasarkan pengamatan, monitoring ketepatan pembuatan surat perlu dilakukan karena lama waktu pembuatan surat merupakan suatu indikator dalam pencapaian kinerja unit yang bertanggungjawab atas ketersediaan dokumen tersebut. Dengan dijadikannya sebagai Key Performance Indicator (KPI), maka monitoring ketepatan waktu pembuatan surat akan dilakukan rutin setiap bulannya lihat Gambar 1.

\section{Pengembangan Aplikasi}

Untuk meningkatkan layanan dan memberikan kemudahan kepada mahasiswa, maka dikembangkan web application dimana mahasiswa dapat melakukan pemesanan surat secara online melalui internet, dalam hal ini melalui http://binusmaya.binus.ac.id. Di samping memberikan kemudahan, juga memberikan keleluasaan pada aspek waktu dimana pemesanan tidak terikat pada waktu operasional layanan SSC karena dapat dilakukan kapan pun dan dimana pun. Mahasiswa dapat melakukan pilihan jenis surat keterangan yang diinginkan bersamaan dengan memasukan data informasi yang dibutuhkan terkait dengan surat keterangan yang dipesan. Hal ini mempercepat proses pembuatan surat karena staf tidak perlu melakukan entri informasi melainkan menggunakan hasil masukan data informasi dari mahasiswa. Validasi atas pemesanan surat pun dapat dilakukan secara otomatis melalui sistem. Contoh salah satu validasi yang dilakukan adalah bahwa surat keterangan mahasiswa aktif hanya dapat dipesan oleh mahasiswa yang terdaftar aktif (memiliki jadwal perkuliahan) pada semester berjalan, dimana hal ini sebelumnya divalidasi secara manual oleh staf. 


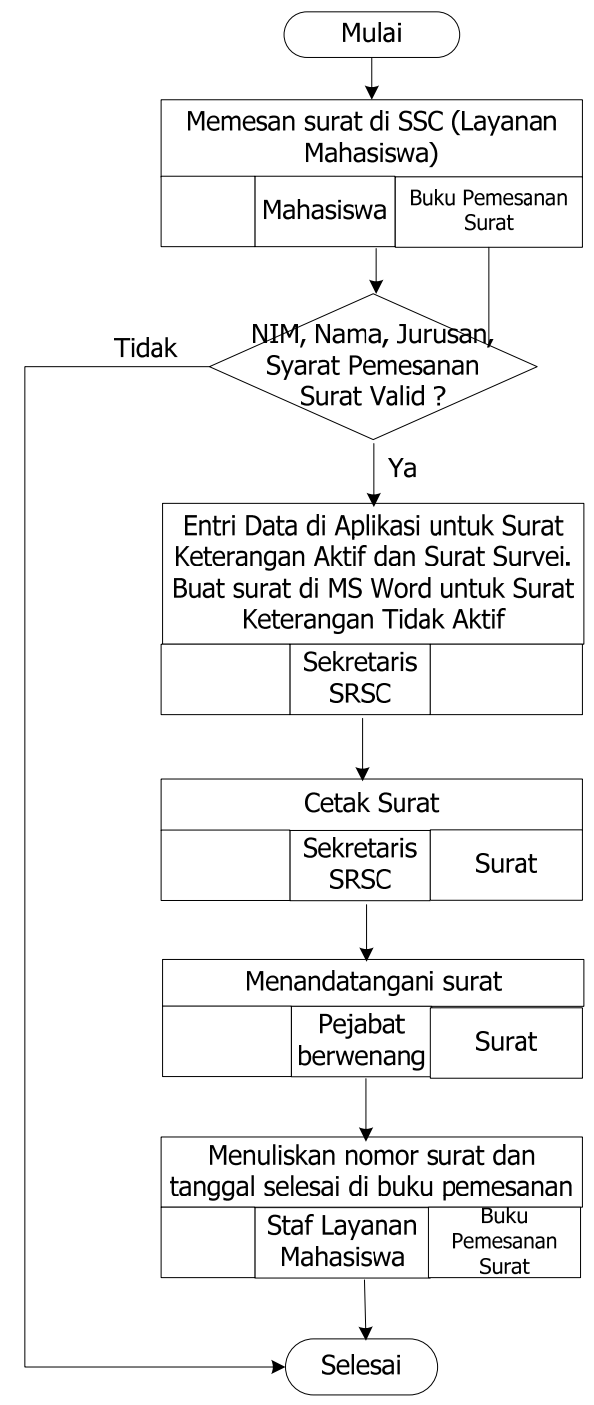

Gambar 1. Alur Proses Sebelum Implementasi Sistem

Data pesanan surat melalui web akan dipantau secara rutin oleh staf yang bertugas, sehingga tanggal pesanan, tanggal selesai proses surat akan didapat secara akurat berdasarkan tanggal sistem komputer. Hal ini memudahkan proses monitoring lama waktu pembuatan surat. Sementara dari sisi mahasiswa akan mendapatkan informasi status pesanan surat, apakah sedang diproses, ditolak, atau sudah selesai. Fasilitas lain yang diberikan adalah informasi bahwa surat yang dipesan sudah selesai diproses melalui private message kepada mahasiswa. Semua hal tersebut dilakukan secara otomatis oleh aplikasi. Proses kerja staf yang lebih mudah dan cepat dinilai mampu meningkatkan efisiensi dan efektifitas kerja administrasi harian lihat Gambar 2.

\section{Evaluasi Efisiensi dan Efektifitas Kerja}

Berdasarkan pengamatan data perbandingan tahun 2007 dan 2008 serta 2009 dimana tahun 2007 adalah data sebelum implementasi sistem dan tahun 2008 serta 2009 adalah data setelah implementasi sistem, tingkat ketepatan waktu pembuatan surat mengalami peningkatan. Jika pada tahun 2007 tingkat ketepatan pembuatan surat sebesar 95,78\%, maka pada tahun 2008 mengalami peningkatan menjadi 98,11\% dan pada tahun 2009 sebesar 98.50\%. Di sisi lain, dari jumlah 
pemesanan surat juga mengalami peningkatan dimana pada tahun 2007 sebesar 7.787 surat, pada tahun 2008 mencapai 8.161 dan di tahun 2009 sejumlah 8.614. Hal ini menunjukkan bahwa dengan diimplementasikannya sistem, peningkatan jumlah pesanan surat tidak menyebabkan terjadinya penurunan persentase ketepatan pembuatan surat. Sehingga evaluasi data menjelaskan bahwa benar telah terjadi efisiensi dan efektifitas kerja administrasi. Tentu saja hal ini berdampak pada peningkatan layanan kepada mahasiswa lihat Tabel 1, 2 dan 3.

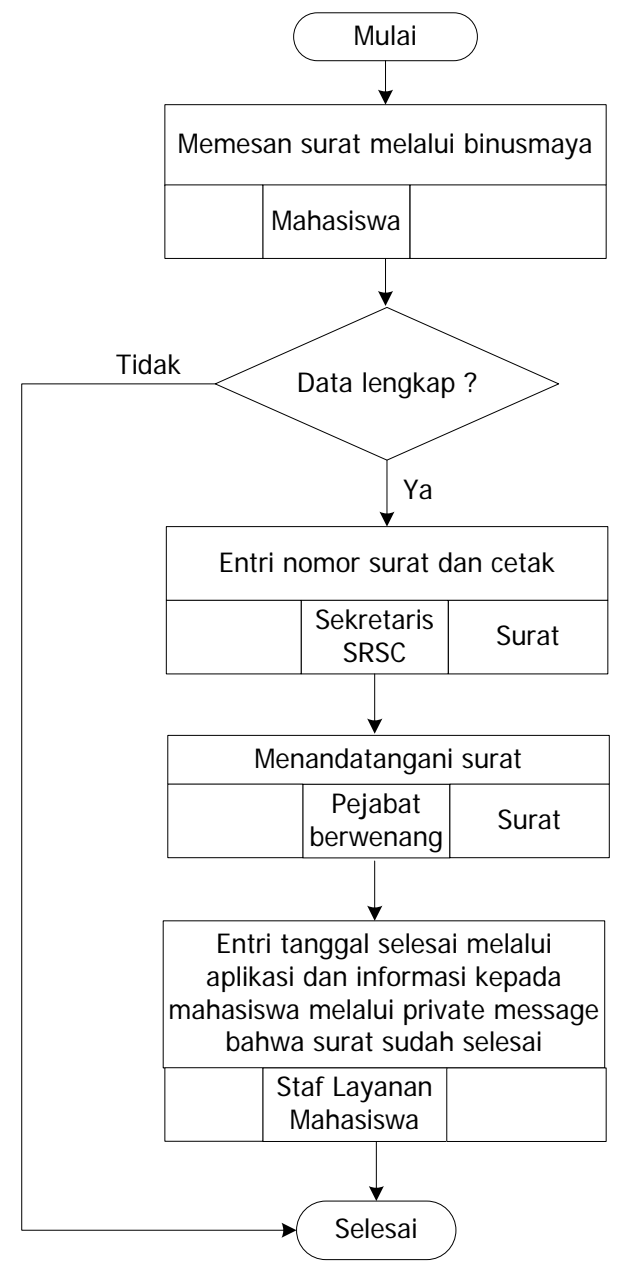

Gambar 2. Alur Proses Setelah Implementasi Sistem

Tabel 1. Data Persentase Proses Surat Melebihi Batas Waktu Sebelum Implementasi di tahun 2007

\begin{tabular}{lrrr}
\hline \multirow{2}{*}{ Bulan } & \multicolumn{2}{c}{ Jumlah Pesanan Surat } & Persentase \\
\cline { 2 - 3 } & $\begin{array}{c}\text { Diproses Tepat } \\
\text { Waktu }\end{array}$ & $\begin{array}{c}\text { Diproses Tidak } \\
\text { Tepat Waktu }\end{array}$ & Ketepatan \\
\hline Januari 2007 & 498 & 1 & $99.80 \%$ \\
Februari 2007 & 577 & 62 & $90.30 \%$ \\
Maret 2007 & 1,347 & 4 & $99.70 \%$ \\
April 2007 & 622 & 4 & $99.36 \%$ \\
Mei 2007 & 780 & 78 & $90.91 \%$ \\
Juni 2007 & 606 & 1 & $99.84 \%$ \\
Juli 2007 & 536 & 41 & $92.89 \%$ \\
\hline
\end{tabular}




\begin{tabular}{lrrr}
\hline Agustus 2007 & 768 & 44 & $94.58 \%$ \\
September 2007 & 1,082 & 76 & $93.44 \%$ \\
Oktober 2007 & 401 & 13 & $96.86 \%$ \\
November 2007 & 337 & 8 & $97.68 \%$ \\
Desember 2007 & 233 & 11 & $95.49 \%$ \\
\hline \multicolumn{1}{c}{ Jumlah } & $\mathbf{7 , 7 8 7}$ & $\mathbf{3 4 3}$ & $\mathbf{9 5 . 7 8 \%}$ \\
\hline
\end{tabular}

Tabel 2. Data Persentase Proses Surat Melebihi Batas Waktu Setelah Implementasi di tahun 2008

\begin{tabular}{lrrr}
\hline \multirow{2}{*}{ Bulan } & \multicolumn{2}{c}{ Jumlah Pesanan Surat } & Persentase \\
\cline { 2 - 3 } & $\begin{array}{c}\text { Diproses Tepat } \\
\text { Waktu }\end{array}$ & $\begin{array}{c}\text { Diproses Tidak } \\
\text { Tepat Waktu }\end{array}$ & $\begin{array}{c}\text { Ketepatan } \\
\text { Januari 2008 }\end{array}$ \\
Februari 2008 & 460 & 27 & $94.46 \%$ \\
Maret 2008 & 942 & 20 & $97.92 \%$ \\
April 2008 & 1,407 & 19 & $98.67 \%$ \\
Mei 2008 & 695 & 9 & $98.72 \%$ \\
Juni 2008 & 548 & 7 & $98.74 \%$ \\
Juli 2008 & 743 & 4 & $99.46 \%$ \\
Agustus 2008 & 458 & 2 & $99.57 \%$ \\
September 2008 & 617 & 8 & $98.72 \%$ \\
Oktober 2008 & 906 & 4 & $99.56 \%$ \\
November 2008 & 579 & 9 & $98.47 \%$ \\
Desember 2008 & 496 & 1 & $99.80 \%$ \\
\hline \multicolumn{1}{c}{ Jumlah } & 310 & 1 & $99.68 \%$ \\
\hline
\end{tabular}

Tabel 3. Data Persentase Proses Surat Melebihi Batas Waktu Setelah Implementasi di tahun 2009

\begin{tabular}{lrrr} 
& \multicolumn{2}{c}{ Jumlah Pesanan Surat } & \\
\cline { 2 - 3 } Bulan & $\begin{array}{c}\text { Diproses Tepat } \\
\text { Waktu }\end{array}$ & $\begin{array}{c}\text { Diproses Tidak } \\
\text { Tepat Waktu }\end{array}$ & $\begin{array}{c}\text { Persentase } \\
\text { Ketepatan }\end{array}$ \\
\hline Januari 2009 & 453 & 16 & $96.59 \%$ \\
Februari 2009 & 705 & 1 & $99.86 \%$ \\
Maret 2009 & 1,383 & 3 & $99.78 \%$ \\
April 2009 & 915 & 25 & $97.34 \%$ \\
Mei 2009 & 762 & 24 & $96.95 \%$ \\
Juni 2009 & 613 & 2 & $99.67 \%$ \\
Juli 2009 & 457 & 3 & $99.35 \%$ \\
Agustus 2009 & 774 & 7 & $99.10 \%$ \\
September 2009 & 786 & 7 & $99.12 \%$ \\
Oktober 2009 & 1,019 & 42 & $96.04 \%$ \\
November 2009 & 412 & 0 & $100.00 \%$ \\
Desember 2009 & 335 & 1 & $99.70 \%$ \\
\hline \multicolumn{1}{c}{ Jumlah } & $\mathbf{8 , 6 1 4}$ & $\mathbf{1 3 1}$ & $\mathbf{9 8 . 5 0 \%}$ \\
\hline
\end{tabular}

Dengan otomatisasi penyimpanan tanggal pemesanan surat dan tanggal proses pembuatan surat, memberikan kemudahan dan keakuratan monitoring ketepatan pembuatan surat. Kemudahan dalam pembuatan surat pun meningkatkan efisiensi kerja staf. Berdasarkan pengamatan, pembuatan surat yang sebelumnya membutuhkan waktu 3 menit per surat dikarenakan validasi masih dilakukan manual, informasi yang dibutuhkan oleh surat diketik oleh staf, berubah menjadi hanya 1 menit per 
surat. Hal ini menunjukkan adanya efisiensi dalam penggunaan waktu dan sumber daya dalam pembuatan surat. Di samping efisiensi dari aspek waktu, efektifitas pembuatan surat pun meningkat karena informasi yang dibutuhkan surat didata oleh mahasiswa secara langsung, sehingga mengurangi kesalahan pengetikan oleh staf pembuat surat. Dengan dimanfaatkannya web application ini, efisiensi pun dirasakan oleh mahasiswa karena untuk mendapatkan surat keterangan hanya cukup datang 1 kali ke SSC, yaitu pada saat pengambilan surat keterangan karena proses pemesanan dan status pembuatan surat dapat dilakukan dan dipantau melalui web.

\section{Interface}

\begin{tabular}{|c|c|c|}
\hline So r & \multicolumn{2}{|c|}{ Wednesday, 08 October $2008::$ Good Morning, MARIA GA } \\
\hline Data Pribadi & \multirow{4}{*}{$\begin{array}{l}\text { Quotes of the day } \\
\text { A room without books is like a body without a soul (Cicero) }\end{array}$} & My Study Performance \\
\hline Registrasi Kuliah & & \multirow[b]{3}{*}{$\ll<$ View Details $\gg$} \\
\hline Kuliah & & \\
\hline Ujian & & \\
\hline Nilai & Private Message! & My Courses \\
\hline $\begin{array}{l}\text { Skripsi / TA / Studi } \\
\text { Lapangan / KP }\end{array}$ & - 19 Sep 2008 - GRIEFING KRSS DAN SKRIPSI & \multirow{3}{*}{$\begin{array}{l}\text { Manajemen Resiko } \\
\text { Berkomputer ( MCL ) } \\
\text { Pengelolaan Fungsi Aud } \\
\text { Sistem Informasi ( MCL } \\
\text { Character Building IV } \\
\text { ( MCL) }\end{array}$} \\
\hline Keuangan & Recent News & \\
\hline $\begin{array}{l}\text { Permohonan Surat / } \\
\text { Layanan }\end{array}$ & $\begin{array}{l}-27 \text { Sep } 2008 \text { - EUSINESS PLAN COMPETITION (BEPC) } 2008 \\
-26 \text { Sep } 2008 \text { - The } 12 \text { th EINUS JOB EXPO }\end{array}$ & \\
\hline Wisuda & $\begin{array}{l}-26 \text { Sep } 2008 \text { - PEMEERTT AHUAN MAHASISWA GAGAL AUTO DEEET UAGN SKS- } \\
\text { 2PELUNASAN SEMESTER GANJLL 2008-2009 TANGGAL } 25\end{array}$ & $\begin{array}{l}\text { Skripsi - Analisis Invest } \\
\text { Sistem Informasi }\end{array}$ \\
\hline
\end{tabular}

Gambar 3. Menu pemesanan surat

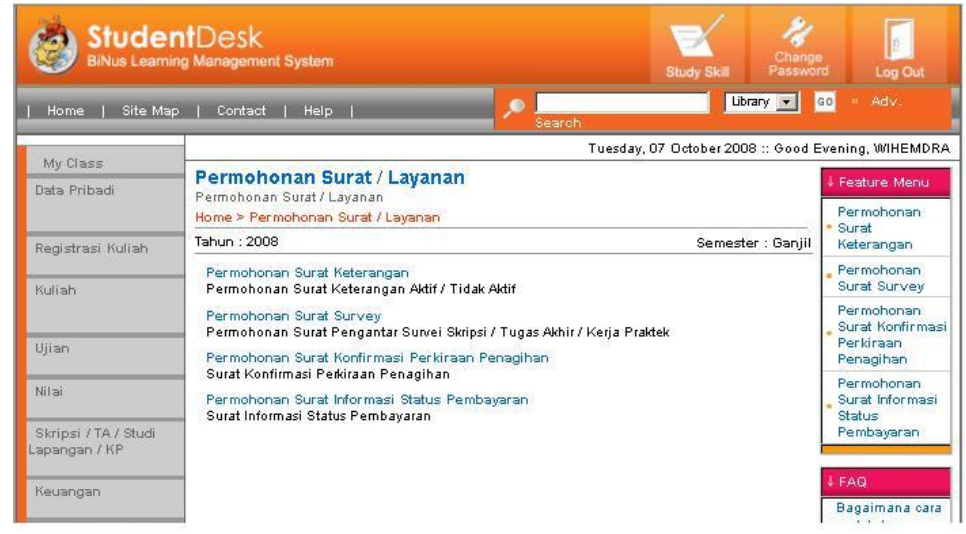

Gambar 4. Pilihan Surat

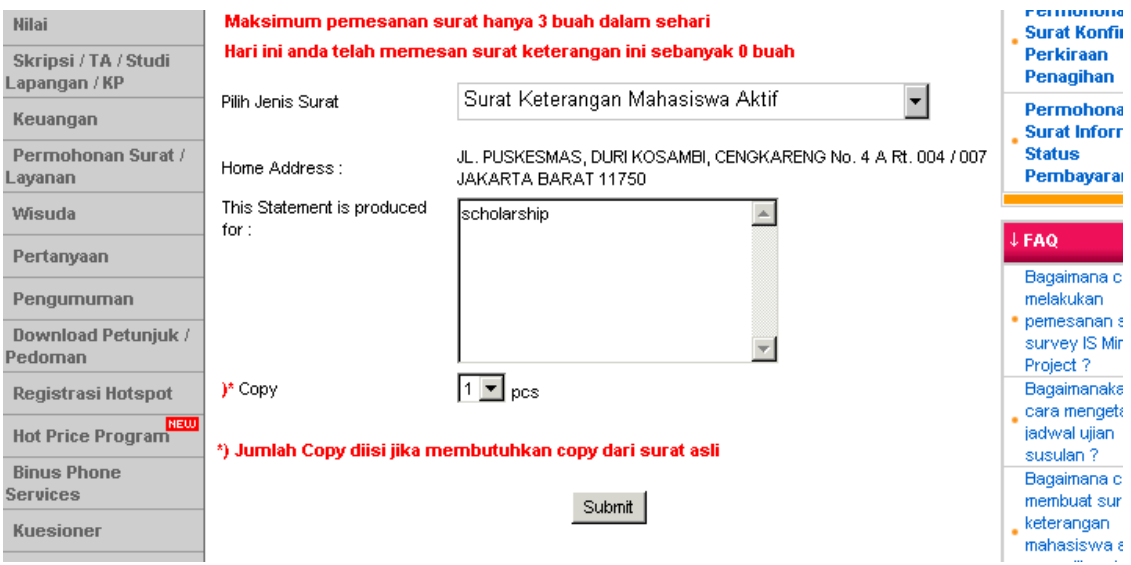

Gambar 5. Isian informasi yang dibutuhkan surat 


\begin{tabular}{|c|c|c|c|}
\hline \multirow[b]{2}{*}{$\begin{array}{l}\text { Class } \\
\text { Pribadi }\end{array}$} & & \multicolumn{2}{|c|}{ Wednesday, 08 October $2008::$ Good Morning, MARIA GABEY } \\
\hline & \multicolumn{2}{|c|}{$\begin{array}{l}\text { Permohonan Surat / Layanan } \\
\text { Permohonan Surat / Layanan }\end{array}$} & $\downarrow$ Feature Menu \\
\hline strasi Kuliah & \multicolumn{2}{|c|}{ Home $>$ Permohonan Surat / Layanan $>$ Permohonan Surat Keterangan } & \multirow{2}{*}{$\begin{array}{l}\text { Permohonan } \\
\text { - Surat } \\
\text { Keterangan }\end{array}$} \\
\hline \multirow{4}{*}{ h } & \multirow{2}{*}{\multicolumn{2}{|c|}{$\begin{array}{l}\text { Permohonan Surat Keterangan } \\
\text { Permohonan Surat Keterangan Aktif / Tidak Aktif }\end{array}$}} & \\
\hline & & & Permohonan \\
\hline & Tahun : 2008 & Semester : Ganjil & Surat Survey \\
\hline & \multirow{2}{*}{\multicolumn{2}{|c|}{$\begin{array}{l}\text { Maksimum pemesanan surat hanya } 3 \text { buah dalam sehari } \\
\text { Pemesanan surat anda akan segera diproses. Silahkan menunggu! }\end{array}$}} & $\begin{array}{l}\text { Permohonan } \\
\text { Surat Konfirmasi }\end{array}$ \\
\hline $\begin{array}{l}\text { isi / TA / Studi } \\
\text { gan / KP }\end{array}$ & & & $\begin{array}{l}\text { Perkiraan } \\
\text { Penagihan }\end{array}$ \\
\hline ngan & \multirow{2}{*}{ Pilih Jenis Surat } & \multirow{2}{*}{$\nabla$} & $\begin{array}{l}\text { Permohonan } \\
\text { Surat Informasi }\end{array}$ \\
\hline $\begin{array}{l}\text { lohonan Surat / } \\
\text { an }\end{array}$ & & & $\begin{array}{l}\text { Status } \\
\text { Pembayaran }\end{array}$ \\
\hline da & \multirow{3}{*}{\multicolumn{2}{|c|}{ Previous Page }} & \\
\hline inyaan & & & $\downarrow$ FAQ \\
\hline Jumuman & & & $\begin{array}{l}\text { Bagaimana cara } \\
\text { melakukan } \\
\text { - pernesanan surat }\end{array}$ \\
\hline
\end{tabular}

Gambar 6. Konfirmasi atas pesanan surat

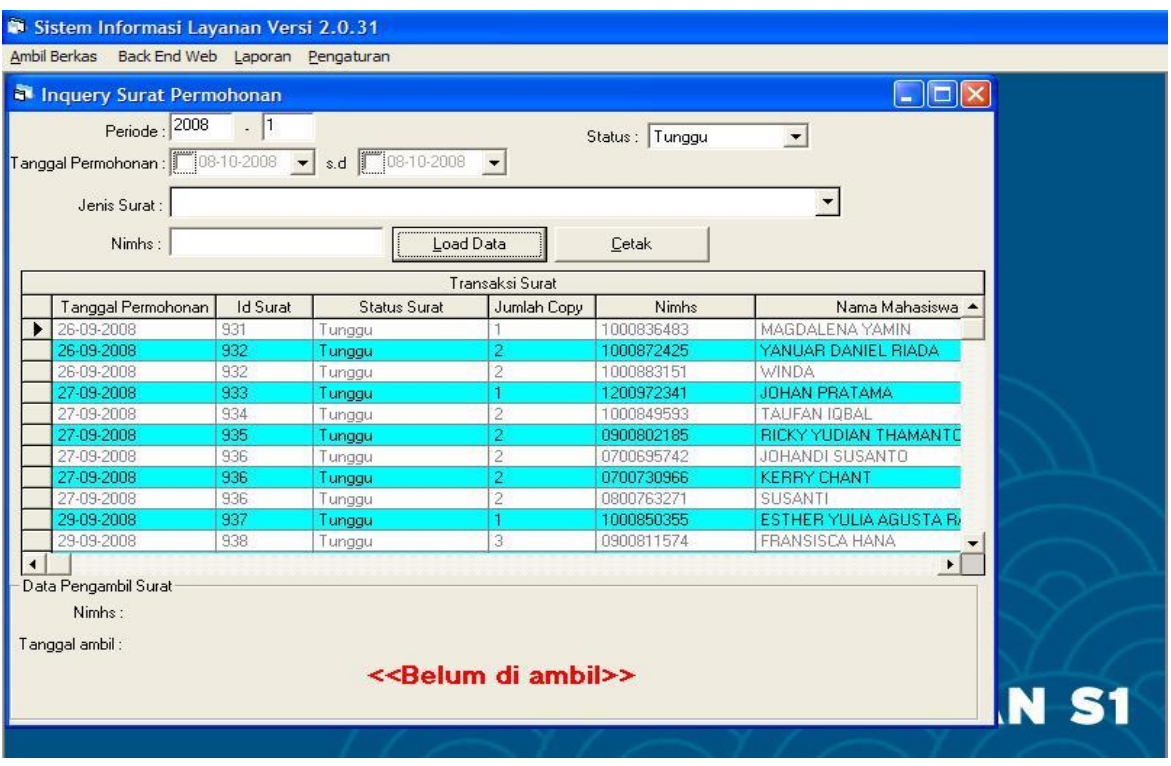

Gambar 7. Daftar pesanan surat

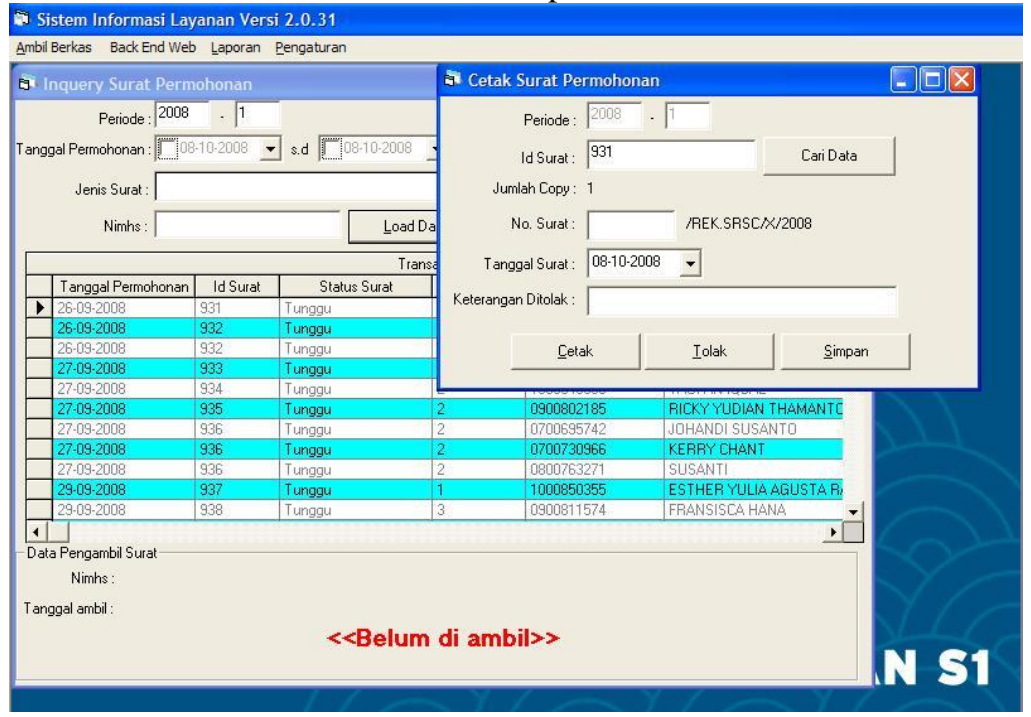

Gambar 8. Proses pencetakan surat 

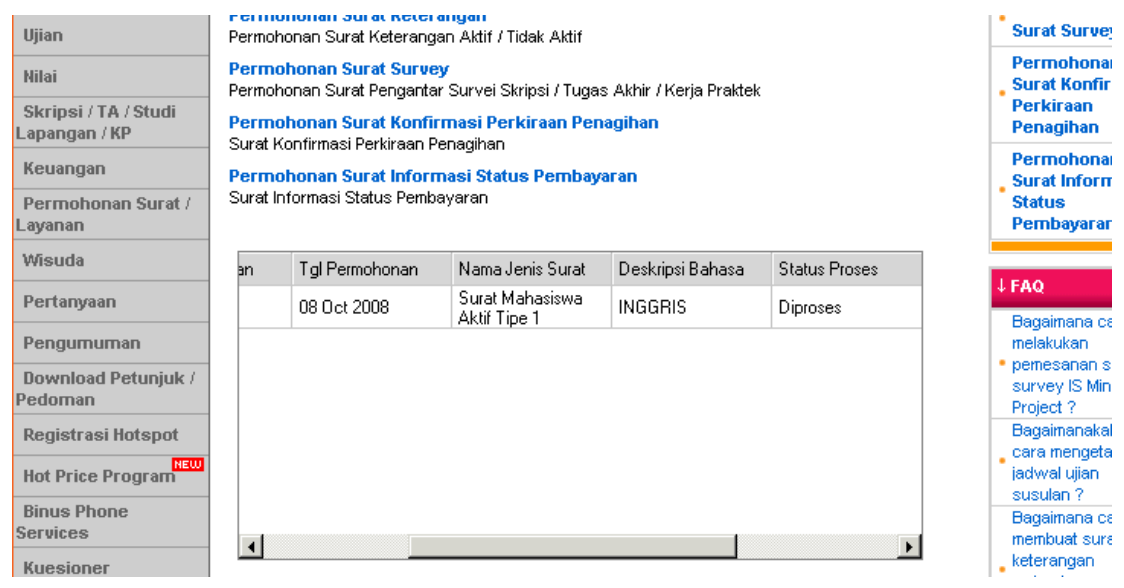

Gambar 9. Status pesanan surat

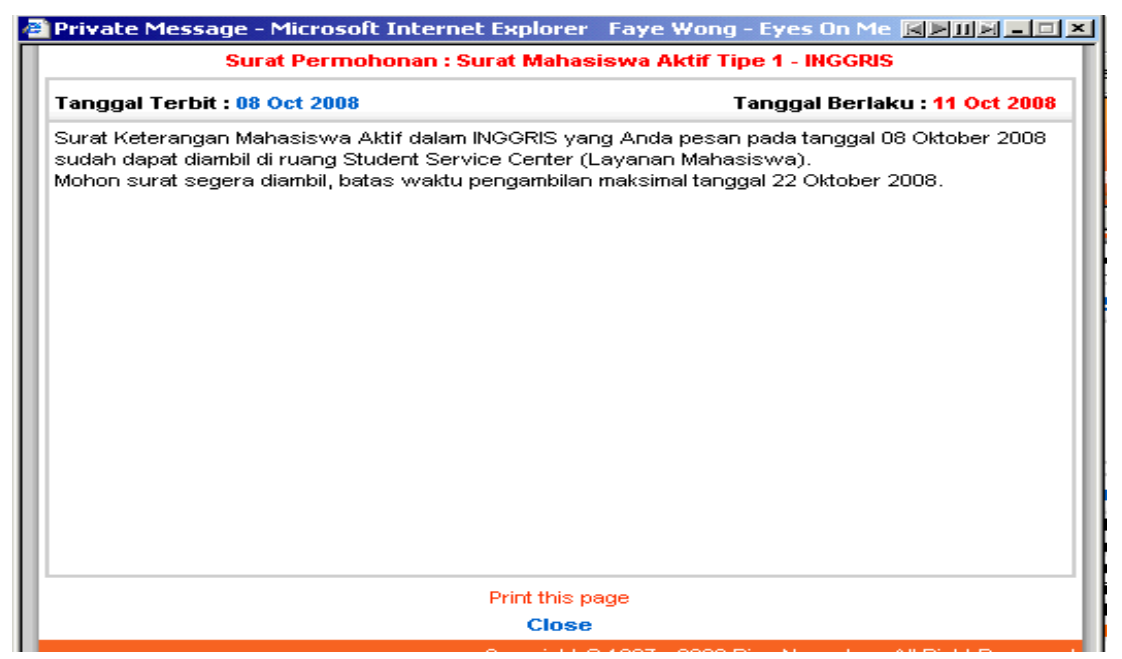

Gambar 10. Fasilitas private message

\section{PENUTUP}

Berdasarkan hasil evaluasi maka disimpulkan bahwa pemanfaatan web application dapat meningkatkan efisiensi dan efektifitas kerja administrasi. Hal ini terlihat dari 4 faktor, yaitu data pencapaian peningkatan ketepatan pembuatan surat sebesar 3\% pada tahun 2008 dan 2009, meskipun jumlah pesanan surat bertambah pada tahun-tahun tersebut. Kedua, penurunan waktu pembuatan surat selama 2 menit per surat. Ketiga adalah kemudahan mahasiswa dalam melakukan pesanan dan mendapatkan surat keterangan. Dan yang terakhir adalah ketepatan dan kemudahan monitoring pembuatan surat.

Melalui web application proses validasi dapat dilakukan secara akurat dan komunikasi 2 arah dapat dilakukan dimana mahasiswa dapat mengetahui status pemesanan dan pembuatan surat serta mendapatkan feedback atas pesanan surat yang dilakukan. 


\section{DAFTAR PUSTAKA}

Anggraini N., Reina, Wihendro. (2009). Pemesanan Surat Online (Laporan BINUS Quality Award. Unpublished)

Lader A., \& Wall L. (2002). Building Web Services and .NET Applications. California: McGraw-Hil 